\title{
Die voedingsoorgang in Suid-Afrika: ' $n$ Uitdaging vir verbeterde voeding en die verligting van armoede
}

\author{
Author: \\ Hester H. Vorster ${ }^{1}$ \\ Affiliation: \\ ${ }^{1}$ Centre for Excellence in \\ Nutrition, North-West \\ University, Potchefstroom \\ Campus, South Africa \\ Correspondence to: \\ Hester Vorster \\ Email: \\ este.vorster@nwu.ac.za \\ Postal address: \\ Private Bag X6001, \\ Potchefstroom 2520, \\ South Africa \\ Dates: \\ Received: 25 Jan. 2011 \\ Accepted: 03 May 2011 \\ Published: 26 Sept. 2011 \\ How to cite this article: \\ Vorster, H.H., 'Die \\ voedingsoorgang in Suid- \\ Afrika: 'n Uitdaging vir \\ verbeterde voeding en die \\ verligting van armoede', \\ Suid-Afrikaanse Tydskrif \\ vir Natuurwetenskap en \\ Tegnologie 30(1), Art. \#29, \\ 7 pages. http://dx.doi. \\ org/10.4102/satnt.v30i1.29
}

Suid-Afrika, soos ander ontwikkelende lande in Sub-Sahara Afrika, bly in gebreke om die Verenigde Nasies se Millennium Ontwikkelingsdoelwitte te haal. In hierdie artikel word daar verduidelik dat hierdie onvermoë waarskynlik verband hou met grootskaalse wanvoeding in Afrika. Ekonomiese ontwikkeling en modernisering het 'n verandering in leefstyl en eetpatrone veroorsaak wat tot oorgewig en verwante siektes lei, voordat die probleem van ondervoeding opgelos is. In Suid-Afrika is ' $n$ derde van die kinders nog steeds ondervoed terwyl byna 'n derde van volwasse mans en meer as die helfte van volwasse vroue reeds oorgewig of vetsugtig is. Hierdie dubbele lading van ondervoeding en oorvoeding lei tot hoë vlakke van beide oordraagbare (infektiewe) en nie-oordraagbare kroniese siektes, wat saam met die menslike immuniteitsgebrekkige virus (MIV) en verworwe immuniteitsgebrek sindroom (VIGS) epidemie verantwoordelik is vir die afname in lewensverwagting in Afrika. Armoede lei tot wanvoeding in swanger vroue, tot wangevoede fetusse, epigenetiese programmering van metaboliese paaie in 'n fetus, lae-geboortegewig babas en kinders met belemmerde fisiese en intellektuele ontwikkeling. Hierdie kinders ontwikkel in volwassenes met beperkte menskapitaal en het ' $n$ verhoogde risiko vir oorgewig en kroniese siektes. Hulle vind dit moeilik om te ontsnap uit die intergeneratiewe siklus van armoede en wanvoeding.

'n Denkraamwerk word voorgestel as basis vir die beplanning van holistiese, transdissiplinêre en multisektoriale programme om ondervoeding en oorvoeding gelyktydig aan te spreek. Verder word daar aanbeveel dat Suid-Afrika meer openbare gesondheidsvoedingkundiges oplei en dat alle gesondheidswerkers beter toegerus word om die goeie voedingstrategieë van die Departement Gesondheid (Direktoraat Voeding) meer doeltreffend te implementeer.

Developing countries, including South Africa, are lagging behind in reaching the United Nations' Millennium Development Goals (MDGs). These countries are at present experiencing a nutrition transition that is an outcome of economic development, urbanisation and acculturation. In this article, the nutritional situation in South Africa based on anthropometric characteristics of its population, is briefly reviewed. The vicious cycle between poverty, undernutrition and an increased vulnerability for over-nutrition and related noncommunicable diseases (NCDs) is explained and hypothesised to be a major determinant of the coexistence of under-nutrition and over-nutrition in developing countries. In South Africa the coexistence of under-nutrition and over-nutrition underlies a double burden of high morbidity and mortality from both infectious and noncommunicable diseases, which is further exacerbated by the human immunodeficiency virus (HIV) and acquired immune deficiency syndrome (AIDS) pandemic. Clearly, it would be difficult to escape this intergenerational vicious circle of poverty and malnutrition, without optimising the nutritional status of all women who plan to become pregnant. There are many psychological reasons, apart from nutrition transition, why people eat more than they need to, including an inherent partiality for refined, sweet, salty and fatty foods. A conceptual framework, based on the constitutional right to food and nutrition security, is proposed to guide policy makers to plan holistic, integrated, transdisciplinary and multisectorial interventions to address under-nutrition and over-nutrition simultaneously. Individuals should be empowered, facilitated and motivated by appropriate education and training programmes and by strategies to improve socio-economic situations to be able to buy or produce food and to make healthy choices. This food environment will be created only if there is a common agenda, or even legislation, to improve the nutritional status in multisectorial and transdisciplinary programmes. The Directorate of Nutrition in the South African Department of Health has an excellent integrated nutrition strategy, but lacks the required implementation capacity. More public health nutritionists should be trained and other health professionals should be better equipped to implement nutritional interventions in all poverty alleviation and health promotion programmes. 


\section{Inleiding Probleemstelling}

Die onlangse hoëvlak samesprekings in New York oor die onvermoë van verskeie wêreldstreke om vordering te maak in die bereiking van die Millennium Ontwikkelingsdoelwitte (MODe) teen 2015, het weereens die aandag gevestig op armoede en wanvoeding in ontwikkelende lande (Schuftan 2010; Waage et al. 2010). Suid-Afrika, soos die ander lande in Sub-Sahara Afrika, is deel van die streek wat die minste vordering toon (Nishida et al. 2009). Verskeie van die MODe betrek, direk of indirek, 'n verbetering in voedingsekerheid en voedselsekerheid (Tabel 1).

Die Verenigde Nasies Kinderfonds (UNICEF) se konsepsuele raamwerk (Margetts 2004) oor die verwante oorsake van wanvoeding word dikwels gebruik om voedingintervensie programme te beplan. Volgens hierdie raamwerk is die onmiddellike oorsake van wanvoeding dié van onvoldoende dieetinname en siekte. Laasgenoemde twee is die gevolg van onvoldoende huishoudelike voedselsekerheid, onvoldoende moederversorging en kinderversorging, gebrekkige gesondheidsdienste en 'n onhigiëniese omgewing. Hierdie groep word die onderliggende oorsake genoem, en word op hulle beurt deur 'n groep basiese oorsake beïnvloed, wat onvoldoende opvoeding en opleiding, onvoldoende beheer oor menslike, ekonomiese en organisatoriese hulpbronne, en ongewensde politieke en ideologiese superstrukture, insluit.

Dit blyk dus dat om wanvoeding te verlig, verskeie verwante oorsake in 'n holistiese, interdissiplinêre plan aangespreek moet word sodat voedselsekerheid en voedingsekerheid gewaarborg word. Voedselsekerheid kan gedefinieer word as die mensereg van vrye en bekostigbare toegang van alle mense ten alle tye en op sosiaal-aanvaarbare wyses, tot voldoende, voedsame, en aanvaarbare voedsel om te groei, te ontwikkel, te werk en te speel (Gross et al. 2000). Mense met voedselsekerheid weet waar hulle volgende maaltyd vandaan gaan kom.

Ten spyte van hierdie kennis is wanvoeding besig om toe te neem in Afrika, wat die bereiking van die MODe vertraag (Nishida et al. 2009). Die toename in wanvoeding betrek beide ondervoeding van veral kinders, en oorvoeding, oorgewig en vetsug van volwassenes en toenemend ook van kinders en adolessente. Oorvoeding in ontwikkelende lande is verwant aan die voedingsoorgang as gevolg van ekonomiese ontwikkeling soos hieronder verduidelik sal word. Een van die grootste uitdagings in hierdie lande is om voedselsekerheid en voedingsekerheid te waarborg en terselfdertyd die negatiewe tendense in eetpatrone en voedingstatus wat tans voorkom, te stuit of in ' $n$ meer positiewe rigting te stuur.

Daar is veelvuldige redes waarom ontwikkelende lande in gebreke bly om die MODe te bereik. Eerstens is daar die veranderinge in dieetpatrone en voedingstofinnames wat met ekonomiese ontwikkeling, verstedeliking en die modernisering of verwestering van lewenstyl gepaard gaan. Hierdie verskynsel word die voedingsoorgang (Vorster 2002) genoem. Ten tweede is daar waarskynlik'n gebrekkige begrip op beleidsvlak oor die verwantskap tussen wanvoeding, onderontwikkeling en armoede (Vorster 2010). 'n Derde rede is moontlik die onvermoë van die meeste ontwikkelende lande om beleid, selfs goeie beleid, doeltreffend in intervensieprogramme en ontwikkelingsprogramme te implementer, dikwels weens gebrekkige hulpbronne, te min opgeleide mense, 'n gebrek aan politieke toewyding, of selfs uit onkunde.

Die doel van hierdie artikel is om die veranderinge in voedingstatus en die nadelige gevolge daarvan in Suid-

TABEL 1: Die Millennium Ontwikkelingsdoelwitte se verwantskap met voeding.

\begin{tabular}{ll}
$\mathrm{Nr}$ & Millennium ontwikkelingsdoelwitte (MODe) \\
\hline $\mathbf{1}$ & $\begin{array}{l}\text { Wis uitermatige armoede en honger uit. Die teiken is om tussen } 1990 \text { en } 2015 \text { die } \\
\text { verhouding mense met ' } \mathrm{n} \text { inkomste van minder as VSA \$1 per dag te halveer. }\end{array}$
\end{tabular}

2 Bereik universele primêre opvoeding. Die teiken is om teen 2015 te verseker dat alle kinders wêreldwyd, seuns sowel as meisies, 'n primêre skool-kursus voltooi.

3 Bevorder geslagsgelykheid en bemagtig vroue. Die teiken is dat teen 2005 tot 2015 geslagsongelykheid in primêre en sekondêre skole verwyder is en dat vroue se lone en posisies (bv. die aantal verteenwoordigers in parlemente) verbeter word.

$4 \quad$ Verminder kindersterftes. Die teiken is om tussen 1990 en 2015 sterftes van kinder jonger as 5 jaar met twee-derdes te verminder.

5 Verbeter moedergesondheid. Die teiken is om tussen 1990 en 2015 die aanta moeders wat tydens geboorte sterf met ' $n$ drie-kwart te verlaag en om universele toegang tot reproduktiewe gesondheidsdienste te verseker.

Bestry MIV en VIGS, malaria en ander siektes. Die teiken is om teen 2015 die verspreiding van MIV en VIGS, en ander siektes soos malaria te stop, en die insidensie van hierdie siektes te verlaag.

7 Verseker omgewingsvolhoubaarheid. Die teiken is om in landsbeleid die beginsels van volhoubare ontwikkeling en bewaring van omgewingshulp-bronne te integreer.

8 Vorm globale vennootskappe vir ontwikkeling deur onder andere teikens vir regverdige en deursigtige handel en finansiële stelsels daar te stel, met ' $n$ fokus op ontwikkelende lande met die grootste nood.
Verwantskap met voedin

Daar word erken dat armoede tot honger lei, maar dit is belangrik om te besef dat hongerte die 'menskapitaal' en die vermoë om te werk en bedreigings en uitdagings te hanteer, verminder, en dus armoede veroorsaak.

Ondervoeding veroorsaak kognitiewe onder-ontwikkeling. Ondervoede kinders het ' $\mathrm{n}$ groter risiko om nie skool-toe te gaan nie asook ' $\mathrm{n}$ risiko om nie te presteer nie.

Welgevoede meisies het ' $n$ beter kans om skoolopleiding te voltooi en beheer uit te oefen op gedragskeuses, soos vermyding van tiener-swangerskappe. Welgevoede moeders se babas het ' $n$ beter kans vir normale fisiese en intellektuel ontwikkeling.

Ondervoeding is direk of indirek verantwoordelik vir meer as $50 \%$ van alle kindersterftes. Wanvoeding is die hoofoorsaak van sterftes in ontwikkelende lande. Wanvoeding word geassosieer met die meeste risikofaktore vir moedersterftes. Die gesondheid en voedingstatus van moeders word belemmer deur onregverdige en bevooroordeelde toegang van vroue tot voedsel, hulpbronne en gesondheidsdienste.

Wanvoeding verlaag immuniteit en weerstand teen aansteeklike siektes. Ondervoeding verhaas die ontwikkeling van VIGS in MIV-geïnfekteerde persone.

Die volhoubare en omgewings-vriendelike produksie van gesonde voedsel is een van die grootste uitdagings van die moderne tyd.

Dit is die ontwikkelende lande wat tans die meeste geraak word ten opsigte van voedselsekerheid en voedingsekerheid, asook ten opsigte van die beskikbaarheid van ongewensde en goedkoop geprosesseerde voedselprodukte as gevolg van onregverdige globale handelspraktyke.

Bron: Eie vertaling en aangepas uit Nishida, C., Shrimpton, R. \& Darnton-Hill, I., 2009, 'Landscape analysis on countries' readiness to accelerate action in nutrition' [Landskap analise op lande se gereedheid om aksie te bespoedig met betrekking tot voedingl, SCN News 37, 4-9; en Waage, J., Banerii, R., Chirwa, E., et al., 2010, 'The Millenium Development Goals: a cross-sectorial analysis and principles for goal setting after 2015. Lancet and London International development Centre Commission. Published online 13 September 2010: www.thelancet.com [04 October 2010]. MIV, menslike immuniteitsgebrekkige virus; VIGS, verworwe immuniteitsgebrek sindroom. 
Afrika te beskryf en om aan te toon hoe wanvoeding ' $n$ gevolg maar ook ' $n$ oorsaak van armoede is. Verder word die belangrikste determinante van wanvoeding in SuidAfrika ontleed. Laastens het die artikel ten doel om 'n denkraamwerk voor te stel wat 'n paradigmaverskuiwing in die formulering van beleid en programme noodsaak om 'n verbetering van voedselsekerheid en voedingsekerheid, en dus van voedingstatus en die verligting van armoede te bewerkstellig.

\section{Wanvoeding in Suid-Afrika}

Wanvoeding is ' $n$ term wat beide ondervoeding ('n gebrek aan makronutriënte, en mikronutriënte of voedingstowwe) sowel as oorvoeding ('n oormaat makronutriënte en dikwels 'n gebrek aan mikronutriënte) insluit. Proteïne, vette en koolhidrate is makronutriënte, terwyl mikronutriente die vitamiene en minerale insluit. Die voedingstatus van SuidAfrikaners is kommerwekkend. Met die voedingsoorgang asook ' $n$ verlaging van fisiese aktiwiteit het ' $n$ situasie ontstaan waar 'n derde van Suid-Afrikaanse kinders nog kronies ondervoed is, terwyl 'n derde van volwasse mans en reeds meer as die helfte van volwasse vroue oorvoed is.

Een moontlike verklaring vir die voorkoms van beide ondervoeding by kinders en oorvoeding by volwassenes, is gewortel in fetale ondervoeding. Daar is toenemend bewyse dat fetale ondervoeding lei tot buitengewone lae geboortegewig en bedenklike fisiese en intellektuele ontwikkeling by kinders. Verder word die fetus as ' $t$ ware geprogrammeer om minder bestand te wees teen oorvoedings-verwante nie-infektiewe siektes (NIS) soos hartkwale en diabetes mellitus later in hulle lewe. Dit kan verklaar waarom ondervoede kinders dikwels in huishoudings voorkom waar die volwassenes oorgewig of vetsugtig is, veral as hulle blootgestel is aan 'n moderne energieryke en mikrovoedingstof-arme dieet.

Die wanvoeding van swanger vroue en die gepaardgaande ondervoeding van die fetus is gewortel in armoede, voedselonsekerheid, 'n gebrek aan versorging, siekte, ontoereikende gesondheidsdienste en ongunstige sosioekonomiese toestande, sowel as onkunde oor'n gebalanseerde dieet. Die skokkende gevolg is dat ' $n$ ondervoede fetus dikwels ontwikkel in ' $\mathrm{n}$ fisies en verstandelik belemmerde individu met ' $n$ onmiddellik verhoogde risiko vir oordraagbare siektes sowel as vir NIS in hulle latere lewe. Sulke individue is nie in staat om die maksimum voordeel te put uit opvoeding nie. As volwassenes het sodanige ingeperkte individue minder potensiaal en sukkel hulle om hulleself te verlos van armoede, en is nie in staat om om te sien na die opvolggenerasie nie. Dit is dus duidelik dat dit baie moeilik sou wees om te ontsnap uit hierdie bose kringloop van armoede en wanvoeding sonder om die voedingstatus van alle vroue wat beplan om swanger te raak, optimaal te verander.

Die voedingsoorgang in Suid-Afrika word geassosieer met ' $n$ groter beskikbaarheid, bekostigbaarheid en verbruik van diereprodukte, gebraaide kitskos, suiker-versoete drankies, souterige en vetterige peuselkos en 'n tekort aan volgraan ontbytkos en vars vrugte en groente. Hierdie sogenaamde 'Westerse' dieet skiet dikwels tekort in terme van dieetvesel, vitamiene en minerale en word geassosieer met 'n verhoogde risiko van vetsug en NIS. Onderontwikkelde individue wat dan boonop so 'n dieet volg, is dus ekstra vatbaar vir NIS. Voedingsoorgang is nie die enigste faktor geassosieer met vetsug nie. Verskeie sielkundige faktore beïnvloed mense om meer as nodig te eet, soos ' $n$ ingebore lus vir verwerkte, soet, souterige en vetterige kosse. Hierdie verskynsel word dan ook deur die voedselindustrie misbruik deur sulke produkte beskikbaar te stel teen bekostigbare pryse en deur gebruik te maak van aggressiewe bemarkingstrategië.

\section{Materiaal en metodes}

'n Denkraamwerk is voorgestel as basis vir beplanningsintervensies om die voedingstatus te verbeter deur ondervoeding en oorvoeding gelyktydig aan te spreek. Die denkraamwerk berus op die grondwetlike reg van mense op voedselsekuriteit sowel as voedingsekuriteit. Dit wys dat individue die reg het op keuses in 'n voedselomgewing wat 'n verskeidenheid van bekostigbare, tradisionele, voedsame, veilige en gesonde kos voorsien. Verder beklemtoon die denkraamwerk dat individue bemagtig, bygestaan en gemotiveer moet word. Hierdie doel kan bereik word deur toepaslike opvoeding en opleidingsprogramme, asook deur strategieë wat daarop gemik is om sosio-ekonomiese toestande te verbeter sodat kos gekoop of geproduseer kan word en gesonde keuses gemaak kan word. Die denkraamwerk bevestig dat so ' $n$ voedsel milieu slegs geskep kan word as alle rolspelers deur middel van 'n gemeenskaplike agenda daarna streef om voedingstatus met multisektoriale of transdissiplinêre programme te verbeter. Selfs wetgewing mag nodig wees om hierdie agenda van optimale voedingstatus en gesondheid af te dwing. Wetgewing sou toepaslik wees byvoorbeeld in die verbanning van advertensies wat ongesonde produkte bemark tydens kinderprogramme op televisie.

'n Antropometriese merker vir voedingstatus in volwassenes is die liggaamsmassa indeks (LMI) wat bereken word deur die massa (in algemene spreektaal, 'gewig') van 'n persoon in kilogram $(\mathrm{kg})$ te deel deur die kwadraat van sy of haar lengte in meter $\left(\mathrm{m}^{2}\right)$. ' $\mathrm{n}$ LMI van minder as $18 \mathrm{~kg} / \mathrm{m}^{2}$ word as ondervoed geklassifiseer, tussen $25.1 \mathrm{~kg} / \mathrm{m}^{2}$ en 30.0 $\mathrm{kg} / \mathrm{m}^{2}$ as oorgewig en groter as $30.0 \mathrm{~kg} / \mathrm{m}^{2}$ as vetsugtig. 'n LMI van $18.0 \mathrm{~kg} / \mathrm{m}^{2}$ tot $25.0 \mathrm{~kg} / \mathrm{m}^{2}$ beteken dus dat 'n persoon 'n 'normale' of 'gesonde' gewig weeg vir sy of haar lengte. Sportmanne en sportvroue met meer as normale spierontwikkeling se gesonde LMI mag hoër wees.

Ondervoeding by kinders kan ook met antropometriese veranderlikes gemeet word. 'n Lae (minder as twee standaardafwykings van die gemiddelde vir die spesifieke groep) gewig-vir-ouderdom dui akute ondervoeding aan terwyl 'n kort lengte-vir-ouderdom belemmerde groei, wat 'n gevolg van kroniese ondervoeding is, aandui. 'n Lae gewig-vir-lengte beteken dat uittering teenwoordig is. 


\section{Resultate}

'n Spesifieke groep Suid-Afrikaners is persentasiegewys geklassifiseer volgens ondergewig, oorgewig en vetsugtig (Tabel 2). Dit is opmerklik dat veral vroue kwesbaar is vir oorvoeding (Puoane et al. 2002) terwyl 13\% van mans steeds ondervoed is. Die 30\% kinders wat ondergewig is en/of belemmerde groei toon, is hoofsaaklik Swart kinders, veral in die plattelandse gebiede van Suid-Afrika (Labadarios et al. 2008).

Oorvoeding veroorsaak oorgewig en vetsug en gaan dikwels gepaard met ondervoeding van mikronutriënte. Daar is dus te veel makronutriënte wat as vet gestoor word, maar te min minerale en vitamiene in die dieet, wat tot lusteloosheid, traagheid en 'n verlaagde 'menskapitaal' lei. Daar is geen twyfel nie dat kroniese ondervoeding in kinders tot belemmerde groei en kognitiewe (intellektuele) onderontwikkeling in die kinderjare lei. Daar is oortuigende bewyse dat juis hierdie onderontwikkelde kinders, 'n verhoogde risiko het vir aansteeklike (infektiewe of oordraagbare) siektes (Martorell 1999), maar terselfdertyd ook meer vatbaar is vir die ontwikkeling van nie-oordraagbare of nie-infektiewe siektes (NIS) in hulle volwasse lewe (Vorster 2005). Dit word algemeen aanvaar dat oorgewig en vetsug van die vernaamste risikofaktore is vir die ontwikkeling van NIS, byvoorbeeld kardiovaskulêre siekte (koronêre hartvatsiekte, hipertensie en beroerte), diabetes mellitus en sommige soorte kankers. Hierdie siektes het in die afgelope paar dekades besonder vinnig toegeneem onder die Swart bevolking in Suid-Afrika (Vorster 2002).

Wanvoeding in Suid-Afrika word dus geassosieer met 'n dubbele lading van voedingsverwante siektes (morbiditeit) en sterftes (mortaliteit). Suid-Afrika het tans die hoogste insidensie van die menslike immuniteitsgebrekkige virus (MIV) wat tot verworwe immuniteitsgebrek sindroom (VIGS) lei (Academy of Science of South Africa 2007). Ondervoeding, oorvoeding en die MIV en VIGS epidemie, kan dus gesien word as 'n drie-dubbele lading van siekte in Suid-Afrika, wat medeverantwoordelik is vir die onnatuurlike hoë vlakke van morbiditeit, mortaliteit en lae lewensverwagting (Bradshaw et al. 2006).

\section{Die verwantskap tussen ondervoeding, vetsug en armoede}

Die dubbele lading van ondervoeding en oorvoeding en veral die vinnige toename in die voorkoms van oorgewig en vetsug in arm ontwikkelende lande is waarskynlik 'n direkte gevolg van die voedingsoorgang (Popkin \& Gordon-Larsen 2004; Vorster 2002). Sulke bevolkings word toenemend blootgestel aan 'n moderne of sogenaamde 'Westerse' dieet met groot hoeveelhede sout, bekostigbare olies en vetterige, suiker-versoete, hoogs-geprosesseerde geriefsvoedsel en versnaperinge tydens hulle ekonomiese ontwikkeling, verstedeliking en die modernisering van hulle leefstyle. Dit is veral opmerklik en kommerwekkend dat oorgewig en die nie-infektiewe kroniese siektes as gevolg van hierdie dieet op 'n jonger ouderdom in ontwikkelende lande as in die ontwikkelde lande voorkom (Kruger et al. 2004; Popkin \& Gordon-Larsen 2004).

Die fetale oorsprong van siekte in volwassenes is waarskynlik verantwoordelik daarvoor dat bevolkings wat verhoogde vlakke van ondervoeding in die verlede gehad het, nou skielik gekonfronteer word met 'n epidemie van kroniese nie-infektiewe siektes. Barker en sy medewerkers (Barker 1992) was die eerste wat waargeneem het dat die voorkoms van koronêre hartvatsiekte in Brittanje hoër was by persone wat lae-gewig babas was as by persone met ' $n$ normale geboortegewig. Vandag is daar duidelike en oortuigende bewyse dat ondervoeding tydens swangerskap die fetus metabolies programmeer om as 'n volwassene (en selfs as adolessent) 'n groter risiko vir vetsug, kardiovaskulêre siekte, diabetes mellitus en sommige kankers te hê. Een van die voorgestelde meganismes (Gluckman et al. 2005) is dat ondervoeding van die moeder epigenetiese veranderinge (metilering van deoksiribonukleïensuur) in die fetus veroorsaak, wat die uitdrukking van die betrokke gene verander. Dit is asof die fetus deur hierdie 'herprogrammering' van metaboliese paaie voorberei word om te oorleef in ' $n$ wêreld waarin min noodsaaklike voedingstowwe beskikbaar gaan wees. Wanneer so 'n 'geprogrammeerde' persoon dan as volwassene blootgestel word aan 'n oormaat makronutriënte, word daar metaboliese paaie 'aangeskakel' wat hierdie makronutriënte vinnig as vet stoor vir latere tye van skaarste. Daar word ook ander moontlike meganismes soos genetiese seleksie van oorgewig persone vir oorlewing voorgestel, maar daar is nog heelwat navorsing nodig voordat ons sal verstaan hoekom ondervoeding in die vroeër jare so maklik tot oorvoeding in latere jare lei.

Daar is geen twyfel nie dat armoede 'n belangrike oorsaak is van wanvoeding van die moeder, en dus, voor geboorte

TABEL 2: Wanvoeding onder Suid-Afrikaners: Aangepas uit Puoane et al. (2002) vir volwassenes en Labadarios et al. (2008) vir kinders, uitgedruk as persentasie van die spesifieke groep.

\begin{tabular}{|c|c|c|c|c|c|}
\hline Groep & Onder-gewig & Belemmerde groei & Oorgewig & Vetsugtig & Oorgewig en vetsugtig \\
\hline SA kinders, 1-9 jaar & 10.0 & 20.0 & 10.0 & 4.0 & 14.0 \\
\hline SA mans, 15 en ouer & 12.9 & - & 21.7 & 7.5 & 29.2 \\
\hline SA vroue, 15 en ouer & 5.6 & - & 26.6 & 30.0 & 56.6 \\
\hline SA Swart mans, 15 en ouer & 12.9 & - & 19.4 & 6.0 & 25.4 \\
\hline SA Swart vroue, 15 en ouer & 4.8 & - & 26.7 & 31.8 & 58.5 \\
\hline
\end{tabular}

Bron: Aangepas uit Puoane, T., Steyn, K., Bradshaw, D., Laubscher, R., Fourie, J., Lambert, V., et al., 2002, 'Obesity in South Africa: the South African demographic and health survey' [Vetsug in Suid-Afrika: die Suid-Afrikaanse demografiese en gesondheidsopname], Ob Res 10, 1038-1048; en Labadarios, D., Swart, R., Maunder, E.M.W., Kruger, H.S., Gericke, G.J., Kuzwayo, P.M.N., et al., 2008, 'Executive summary of the national Food Consumption Survey Fortification baseline (NFCS-FB-1) South Africa, 2005' [Samevatting van die Nasionale Voedsel Verbruik Ondersoek Fortifikasie Aanvangslyn (NFCS-FB-1) Suid-Afrika, 2005], S. Afr. J. Clin. Nutr., suppl. series 2. Nota: Waardes word weergegee as persentasie. SA, Suid-Afrikaanse. 


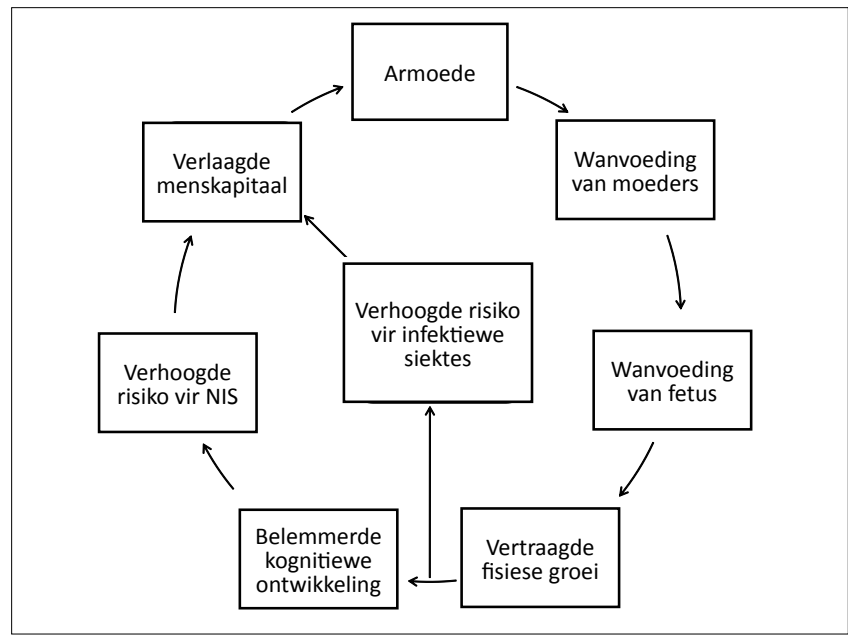

Bron: Oorspronklike data

FIGUUR 1: Die bose kringloop van armoede en wanvoeding, met ' $n$ verhoogde risiko vir aansteeklike (infektiewe) siektes in die kinderjare sowel as ' $n$ langtermyn groter vatbaarheid vir nie-infektiewe siektes.

van ondervoeding van die fetus, en na geboorte van klein kinders (Vorster 2010). Ondervoeding tydens die fetale lewe en kinderjare het fisiese en intellektuele onderontwikkeling tot gevolg (Figuur 1). Martorell (1999) beskryf hoe hierdie kinders 'n groter risiko loop vir belemmerde groei en aansteeklike (infektiewe) siektes. Hy wys ook daarop dat hulle nie opvoedingsgeleenthede in die skool optimaal kan benut nie en in volwassenes met verminderde 'menskapitaal' ontwikkel. Terselfdertyd loop hulle 'n groter risiko vir die nie-infektiewe siektes (Martorell 1999). Hulle is dikwels nie in staat om vir hulself en vir hulle kinders te sorg nie en bly dus arm. Die bose kringloop van armoede en wanvoeding word sodoende van die een generasie na die volgende voortgesit (Vorster 2010). Dit is duidelik uit die figuur dat hierdie siklus van wanvoeding en armoede net onderbreek kan word as die voedingstatus van toekomstige swanger vroue, die fetus en jong kinders verbeter word (Vorster 2005).

\section{Die determinante van wanvoeding in Suid-Afrika}

Ditisreedsgenoemdatondervoedingdeurvoedselonsekerheid en gevolglike onvoldoende voedselinname, sowel as siekte veroorsaak word. Die oorgewig en vetsug wat tydens latere kinderjare, adolessensie en volwasse lewe ontwikkel, is die gevolg van 'n dieet wat te veel energie en te min vitamiene en minerale bevat. 'Te veel energie' beteken dat meer energie (in die vorm van koolhidrate, proteïene en vette) as wat deur fisiese aktiwiteit benodig word, ingeneem word. Hierdie dieet word soms 'n 'Westerse' dieet genoem en bestaan tipies uit uitermate soet, sout, olierige, vetterige, lae-vesel (hoogs verfynde) geriefsvoedsel en drank wat al hoe meer bekostigbaar en toeganklik word vir mense wat besig is om te verstedelik. Dit is veral die groter beskikbaarheid en bekostigbaarheid van voedsel van dierlike oorsprong wat in vet en/of olie gebraai word, asook suiker-versoete koeldrank, wat met die vinnige toename in oorgewig persone verband hou (Popkin \& Gordon-Larsen 2004; Vorster et al. 1997). Selfs in plattelandse streke is hierdie produkte toenemend beskikbaar teen pryse wat ryk en arm kan bekostig en word dikwels gebruik om 'n dieet wat hoofsaaklik uit mieliepap as stapelvoedsel bestaan, aan te vul. Dit kan tereg gesê word dat die modernisering van leefstyl in Afrika lei tot 'n dieet wat energie-dig is maar arm aan dieetvesel en mikronutriënte vergeleke met die tradisionele lae-vet, hoë-vesel Afrikadieet. Dit is dus waarskynlik hierdie voedingsoorgang of verandering in dieetpatrone en nutriëntinnames wat die vinnige toename in oorgewig en vetsugtigheid veroorsaak, gekoppel aan 'n leefstyl wat al hoe minder fisiese aktiwiteit noodsaak. Nog 'n bydraende faktor mag wees dat mense wat op enige stadium in die verlede honger was, meer sal eet as wat hulle regtig nodig het wanneer hulle blootgestel word aan 'n oormaat voedsel. Terselfdertyd is hierdie 'nuwe' lae-kwaliteit dieet arm aan mikronutriënte, wat tesame met voedselonsekerheid, 'n onhigiëniese omgewing en onvoldoende versorging van babas en kinders, volgehoue ondervoeding veroorsaak.

Die bogenoemde determinante van wanvoeding is gewortel in ' $n$ kombinasie van armoede en 'n gebrekkige kennis oor gesonde voeding. Maar daar is baie Suid-Afrikaners wat ten spyte van voedselsekerheid en genoegsame kennis oor voeding, meer eet en drink as wat hulle nodig het en gevolglik oorgewig of vetsugtig is. Bykomend tot die veelvuldige sielkundige oorsake van hoekom mense te veel eet, het die meeste mense 'n ingebore voorliefde vir soet, sout en vetterige voedsel en drank. Hierdie voorliefde word deur die voedselindustrie uitgebuit deur sulke produkte teen bekostigbare pryse beskikbaar te stel en aggressief te bemark (Lang \& Heasman 2004).

\section{'n Denkraamwerk vir verandering}

Die uitdaging in Suid-Afrika en ander ontwikkelende lande is om met beperkte hulpbronne ondervoeding en oorvoeding met dieselfde intervensieprogramme aan te spreek. Dit impliseer dat daar op optimale voeding gefokus moet word.

Die grondwet van Suid-Afrika, Artikels 27(i) en 28(i)(c) van die Republiek van Suid Afrika, No. 108 van 1996 (Grondwetlike Hof 1996) beskerm voedselsekerheid en voedingsekerheid van alle burgers as 'n basiese mensereg. Die omvang van wanvoeding in Suid-Afrika toon egter dat daar nie hieraan voldoen word nie. Die vraag is dus wat anders as tans gedoen kan word om hierdie reg te verwesenlik.

'n Denkraamwerk kan die basis vorm vir beplanning van intervensies om voedingstatus te verbeter en dus uiteindelik armoede te help verlig (Figuur 2). Die linkerkant van die figuur toon aan dat alle Suid-Afrikaners die reg het tot 'n voedselomgewing waaruit gesonde voedselkeuses gemaak kan word wat totoptimale voeding sallei. Inhierdieomgewing moet voldoende nutriëntryke, veilige (ongekontamineerde) voedsel beskikbaar en bekostigbaar wees. Die middel van die figuur beklemtoon dat mense voldoende ingelig en bemagtig moet word om gesonde keuses te maak. Hulle moet dus verstaan watter voedselkombinasies noodsaaklik is vir 'n gebalanseerde dieet wat hulle terselfdertyd teen kroniese siektes sal beskerm. Dus moet mense weet hoe om ' $n$ dieet te kies wat ondervoeding en oorvoeding sal 


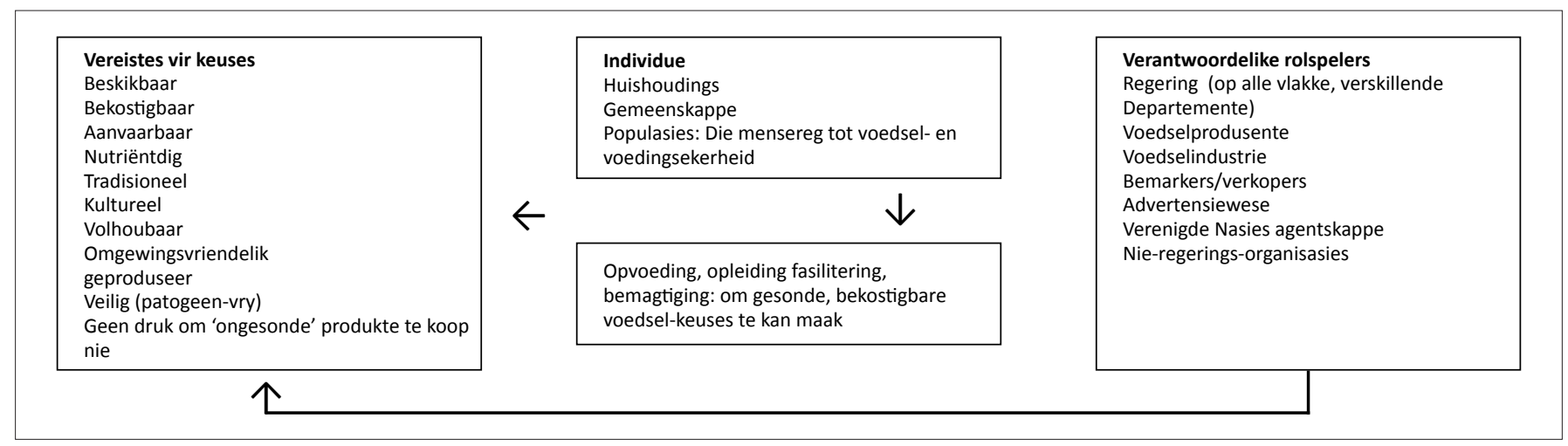

Bron: Oorspronklike data

FIGUUR 2: 'n Konseptuele raamwerk vir die beplanning van intervensies vir voedselsekerheid en voedingsekerheid, asook die optimalisering van voedingstatus en gesondheid.

voorkom. Die regterkant van die figuur lys sommige van die rolspelers wat verantwoordelik is om die voedselomgewing en die voedingsomgewing te skep. Die meganismes via beleid, strategieë en aksies waardeur hierdie rolspelers die omgewing skep en mense bemagtig, is veelvuldig en behoort by al die rolspelers te oorvleuel. Hierdie meganismes lê buite die veld van hierdie artikel, maar daar is veral drie punte uit die raamwerk wat, as dit anders as op hede gedoen word, vinniger mag lei tot voedselsekerheid en voedingsekerheid, en dus tot ' $n$ bereiking van die MODe in ontwikkelende lande.

Die eerste is 'n algemene doelwit om mense deur werkskepping te bemagtig om self voedsel te produseer of te kan bekostig om dit te koop. Dit is teenstrydig met huidige programme waar voedselaanvullings en voedingaanvullings deur die regering en ander nie-regeringsorganisasies gratis uitgedeel word, maar in lyn met die bekende spreekwoord wat lui dat dit beter is 'om mense te leer om vis te vang eerder as om hulle ' $n$ vis te gee om te eet'. Natuurlik sal daar altyd in enige samelewing, maar veral in die ontwikkelende wêreld, kwesbare groepe wees wat voedselhulp en voedingshulp benodig.

Tweedens moet mense opgelei en opgevoed word om die regte, gesonde voedselkeuses te maak. Dit is ' $n$ groot onderneming, omdat mense gemotiveer en geïnspireer moet word om hulle voedselgedrag te verander. Dit impliseer dat 'n groter kapasiteit geskep moet word om voedingsvoorligting op alle vlakke van die samelewing te doen. Bykomend moet strategië en bemarkingsprogramme gebruik word waarvoor daar wetenskaplike bewyse bestaan dat dit wel voedingsgedrag kan verander. Daar moet in gedagte gehou word dat mense voedsel en nie nutriënte of voedingstowwe eet nie. Die opvoedingsprogram vir die algemene publiek moet byvoorbeeld gebasseer word op kort, bemarkbare boodskappe wat fokus op die verskillende voedselgroepe wat 'n gesonde dieet sal waarborg.

Die derde belangrike punt is dat daar groter interaksie en samewerking tussen al die rolspelers (wat aan die regterkant van Figuur 2 aangetoon word) behoort te wees. Dit beteken dat interdissiplinêre en multisektoriale voedselbeleid en voedingsbeleid, asook intervensieprogramme, 'n voorvereiste vir sukses is. Dit kan net gebeur as die verskillende rolspelers mekaar se agendas respekteer en as hulle saamwerk om 'n gemeenskaplike agenda vir die verbetering van voedingstatus en gesondheid ondersteun. Dit mag byvoorbeeld nodig wees dat een rolspeler met meer 'mag' ' $n$ ander rolspeler beïnvloed of dwing om anders op te tree. So byvoorbeeld is daar 'n vermoede dat die voedselindustrie en advertensiewese slegs deur wetgewing oortuig sal word om nie ongewensde voedsel en drank aan kinders tydens televisiespitstye te bemark nie. Dit is egter waarskynlik dat die grootste druk om gesonde produkte te bemark van 'n ingeligte verbruikerskorps sal moet kom.

\section{Gevolgtrekkings}

Die fokus van hierdie artikel is die probleem van wanvoeding in Suid-Afrika en wat ons anders moet doen om die probleem met meer sukses aan te spreek sodat SuidAfrika die MODe betyds sal kan haal. Die Suid-Afrikaanse Departement van Gesondheid se Direktoraat Voeding het 'n goed gemotiveerde voedingstrategie (Department of Health 1995) wat gebaseer is op die huidige voedingsituasie in Suid-Afrika. 'n Onlangse ontleding van die implementering van die bestaande beleid (Department of Health 2010) het duidelik aangetoon dat een van die grootste uitdagings vir die toekoms is om genoeg kapasiteit te skep om die huidige beleid te implementeer. Dit beteken dat tersiêre instellings in Suid Afrika meer gemeenskaps- en openbare voedingkundiges sal moet oplei, en dat gesondheidswerkers op alle vlakke in die gesondheisprofessies beter toegerus moet word om voedingbeleid te verstaan en te implementeer. Dit is noodsaaklik dat ontwikkelingsprogramme wat poog om armoede te verlig ook intervensies insluit wat voedingstatus sal verbeter.

\section{Literatuurverwysings}

Academy of Science of South Africa, 2007, HIV/AIDS, TB and nutrition. Scientific inquiry into the nutritional influences on human immunity with special reference to HIV infection and active TB in South Africa [MIV/VIGS, TB en voeding. ' $n$ Wetenskaplike ondersoek na die voedingswaarde invloed op die menslike immuniteit met spesiale verwysing na MIV-infeksie en aktiewe TB in Suid-Afrika], Academy of Science of South Africa, Pretoria.

Barker, D.J.P. (ed.), 1992, 'Fetal and infant origens of adult disease' [Die fetale en baba oorsprong van volwasse siektes], British Medical Journal, 310(411), 1-343. 
Bradshaw, D., Schneider, M., Norman, R. \& Bourne, D., 2006, 'Mortality patterns of chronic diseases of lifestyle in South Africa' [Mortaliteitspatrone van chroniese siektes met betrekking tot leefstyl in Suid-Afrikal, in K. Steyn, J. Fourie \& N. Temple siektes met betrekking tot leefstyl in Suid-Afrika], in K. Steyn, J. Fourie \& N. Temple
(eds.), Chronic diseases of lifestyle in South Africa: 1995-2005, Technical Report, pp. 9-22, South African Medical Research Council, Cape Town.

Department of Health, 2010, Landscape analysis on countries' readiness to accelerate action to reduce maternal and child undernutrition: nationwide accelerate action to reduce maternal and child undernutrition: nationwide country assessment in south Africa. Draft report [Landskap analise op lande se gereedheid en kind. Landswye Suid-Afrikaanse assessering], Department of Health, Nutrition,
Pretoria.

Department of Health, 1995, Integrated Nutrition Programme [Geïntegreerde voedingsprogram], Department of Health, Pretoria.

Gluckman, P.D., Hanson, M.A. \& Pinal, C. , 2005, 'The developmental origins of adult disease' [Die ontwikkelingsoorsprong van volwasse siektes], Maternal \& Child Nutrition, 1(3), 130-141. doi:10.1111/j.1740-8709.2005.00020.x, PMid:16881892

Gross, R., Schoeneberger, H., Pfeifer, H. \& Preuss, H-J.A., 2000, 'The four dimentions of food and nutrition security: definitions and concepts' [Definisies en konsepte van die vier dimensies van voedsel- en voedingveiligheid], Nutrition and food security, Deutsche Gesellschaft für Technische Zusammenarbeit (DTZ) GmbH, April, 01-17.

Kruger, H.S., Margetts, B.M. \& Vorster, H.H., 2004, 'Evidence for relatively greater subcutaneous fat deposition in stunted girls in the North-West Province, South Africa, as compared with non-stunted girls' [Bewyse van relatief grote onderhuldse gestremde meisies, in die Noordwes provinsie, Suid-Afrika], Nutrition 20,564569. doi:10.1016/j.nut.2004.03.002, PMid:15165620

Labadarios, D., Swart, R., Maunder, E.M.W., Kruger, H.S., Gericke, G.J., Kuzwayo, P.M.N., et al., 2008, 'Executive summary of the national Food Consumption Survey Fortification baseline (NFCS-FB-1) South Africa, 2005' ['Samevatting van die nasionale Voedsel Verbruik Ondersoek Fortifikasie aanvangslyn (NFCS-FB-1) Suid-Afrika 2005'], S. Afr. J. Clin. Nutr., suppl. series 2.

Lang, T. \& Heasman, M., 2004, Food wars. The global battle for mouths, minds and markets [Voedseloorloë. Die globale geveg om monde, gedagtes en markte] Earthscan, London, UK.

Margetts, B.M., 2004, 'An overview of public health nutrition', in M.J. Gibney, B.M. Margetts, J.M. Kearney \& L. Arab (eds.), Public Health Nutrition, pp. 1-25, Blackwell, Oxford, UK.

Martorell, R., 1999, 'The nature of child malnutrition and its long-term implications' [Die aard en natuur van wanvoeding by kinders en die langtermyn nagevolge] Food and Nutrition Bulletin 20(3), 288-292.
Nishida, C., Shrimpton, R. \& Darnton-Hill, I., 2009, "'Landscape analysis on countries" readiness to accelerate action in nutrition' [Landskap analise op lande se readiness to accelerate action in nutrition 'Landskap analise op lande se 4-9.

Popkin, B.M. \& Gordon-Larsen, P., 2004, 'The nutrition transition: worldwide obesity dynamics and their determinants' [Die voedingsoorgang: wêreldwye vetsug dinamika en determinante], Int. J. Obes. 28, S2-S9. doi:10.1038/sj.ijo.0802804 PMid:15543214

Puoane, T., Steyn, K., Bradshaw, D., Laubscher, R., Fourie, J., Lambert, V., et al., 2002 'Obesity in South Africa: the South African demographic and health survey' [Vetsug in Suid-Afrika: die Suid-Afrikaanse demografiese en gesondheidsopname], Ob Res 10, 1038-1048.

Schuftan, C., 2010, October blog. The Millenium Development Goals: who for, and what for? [Oktober-blog. Die Millenium ontwikkelingsdoelwitte: Vir wie en waarvoor?] viewed 04 October 2010, from http://www.wphna.org/claudioschuftanoct2010. asp

Suid-Afrikaanse Grondwetlike Hof, 1996, Die Grondwet van die Republiek van SuidAfrika, 1996, Wet 108 van 1996, Juta en Kie (Beperk), Pretoria.

Vorster, H.H., 2010, 'The link between poverty and malnutrition: A South African perspective' ['n Suid-Afrikaanse perspektief op die skakel tussen armoede en wanvoeding], Health SA Gesondheid 15(1), Art \#435, 6 pages. doi:10.4102/hsag. v15i1.435

Vorster, H.H., 2005, 'Early nutritional influences on obesity, diabetes, and cardiovascular disease risk' [Die invloed van vroeë voedingsbehoeftes op vetsug, diabetes en kardiovaskulêre siektes], Maternal \& Child Nutrition 1(3), 125-127. diabetes en kardiovaskulere siektes], Maternal \& Child

Vorster, H.H., 2002, 'The emergence of cardiovascular disease during urbanisation of Africans' [Die opkoms van kardiovaskulêre siektes tydens die verstedeliking van Afrikaners], Public Health Nutrition 5(1A), 239-243. doi:10.1079/PHN2001299

Vorster, H.H., Oosthuizen, W., Jerling, J.C., Veldman, F.J. \& Burger, H.M., 1997, The nutritional status of South Africans. A review of the literature from 1975-1996. Part 1 and part 2 [Suid-Afrikaners se voedingswaarde status. ' $n$ Literatuuroorsig van 1975-1996. Deel 1 en deel 2], Health Systems Trust, Durban.

Waage, J., Banerji, R., Chirwa, E., et al., 2010, 'The Millenium Development Goals: a cross-sectorial analysis and principles for goal setting after 2015' [Die Millenium Ontwikkelingsdoelwitte: ' $n$ Kruis-sektor analise en beginsels vir doelwitstelling na 2015], Lancet and London International development Centre Commission, viewed 04 October 2010, from www.thelancet.com 